Turkish Psychological Counseling and Guidance Journal

Türk Psikolojik Danışma ve Rehberlik Dergisi
Özyürek et al. (2021)

Vol: 11 Number: 63 Page: 433-455 ISSN: 1302-1370

RESEARCH

Open Access

ARAŞTIRMA

Açık Erişim

\title{
An Examination of the Opinions of Faculty Members on Critical Accreditation Issues in Counselor Education in Turkey
}

\author{
Türkiye'deki Psikolojik Danışman Ë̈itiminde Kritik Akreditasyon Konular ile İlgili Öğretim Elemanlan \\ Görüslerinin Incelemesi
}

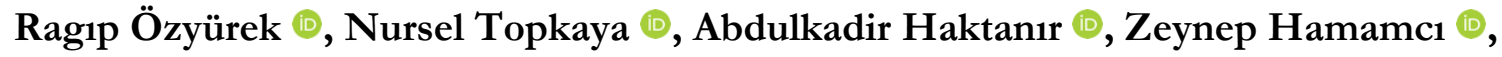

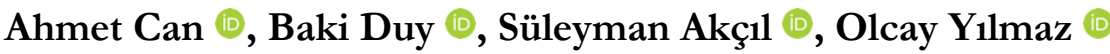

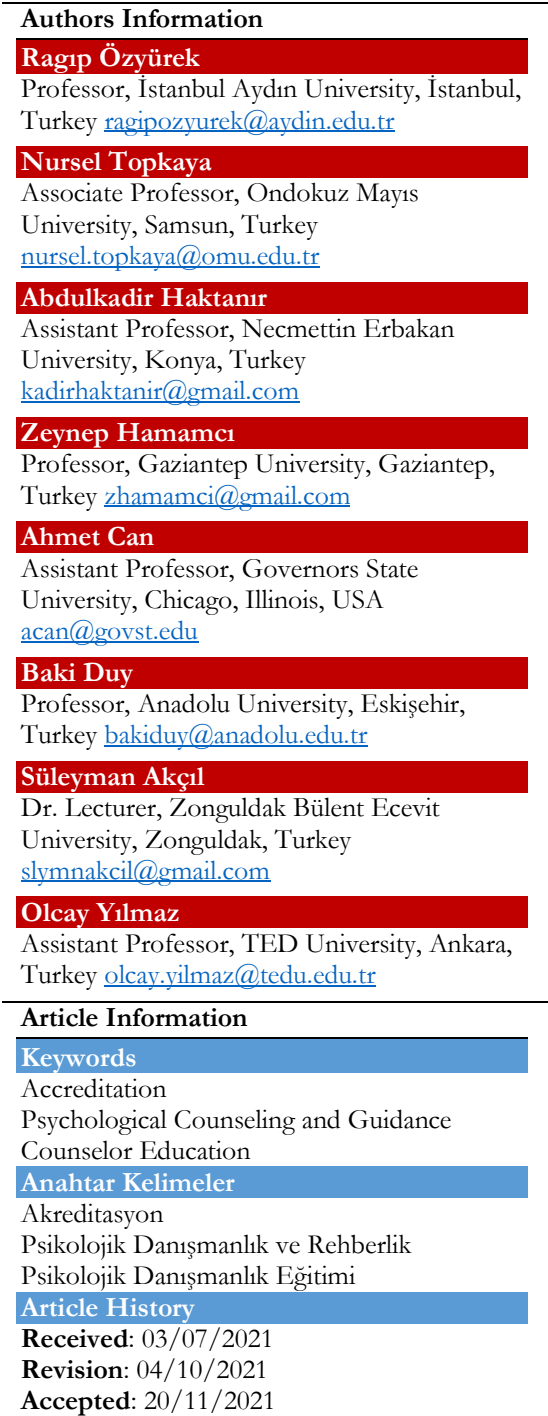

\section{ABSTRACT}

The lack of counselor education standards set by professional organizations increases the necessity for accreditation studies. Therefore, this descriptive study aimed to investigate the opinions of counselor educators working in Turkish public and private universities' counselor education programs on critical standards/criteria of the accreditation process. A total of 201 counselor educators aged between 24 to 88 years participated in the study. Data were collected through a demographic form as well as a survey that was developed by the researchers. Data were analyzed both quantitatively and qualitatively. The results of the study showed that the majority of the participants supported the idea of establishing an independent counseling-specific accreditation organization that accredits counseling programs in Turkey. Implications of the findings, as well as limitations and recommendations, are shared for future research in the study.

\begin{abstract}
ÖZET
Psikolojik danışman eğitimine yönelik profesyonel organizasyonlar tarafindan belirlenmiş standartlar olmaması akreditasyonla ilgili araştırmaların yapılması gerekliliğini arttırmaktadır. Bu nedenle, bu betimsel çalışma, Türkiye'deki devlet ve vakıf üniversitelerin Psikolojik Danışmanlık ve Rehberlik (PDR) anabilim dallarında görev yapan psikolojik danışman eğitimcilerinin, psikolojik danışman eğitimi programlarının akreditasyonu sürecindeki kritik standartlar/ölçütler konularındaki görüşlerini incelemeyi amaçlamaktadır. Çalışma kapsamında 24-88 yaş arası 201 katılımcıya ulaşılmıştır. Çalışmanın verileri demografik formun yanısıra araştırmacılar tarafindan geliştirilen bir anketle toplanmıştır. Çalışmadaki veriler nitel ve nicel olarak incelenmiştir. Araştırmanın sonuçları, katılımcıların büyük çoğunluğunun sadece psikolojik danışmanlık ve rehberlik programlarını akredite eden bağımsız bir akreditasyon organizasyonun kurulması fikrini desteklediklerini ortaya koymuştur. Bulguların çıkarımlarıyla birlikte sınırlılıkları ve yeni araştırmalara öneriler araştırmada paylaşılmıştır.
\end{abstract}

Cite this article as: Özyürek, R., Topkaya, N., Haktanır, A., Hamamc1, Z., Can, A., Duy, B., Akç1, S., Yılmaz, O. (2021). An examination of the opinions of faculty members on critical accreditation issues in counselor education in Turkey. Turkish Psychological Counseling and Guidance Journal, 11(63), $433-455$. 


\section{INTRODUCTION}

The first studies on counseling and guidance emerged in the USA at the beginning of the 1900s and Turkey caught up around the 1950s (Korkut \& Mizikac1, 2008). Though the first counselor education program was opened in 1982, counselor education programs were first listed in the Measuring, Selection and Placement Center (MSPC) guidebook in 1983 (as cited in Özyürek, 2010b). As counselor education programs become more common nationwide, counselor educators began focusing on improving the quality of undergraduate education (Akkoyun, 1995; Atıc1, Özyürek, \& Çam, 2006; Doğan, 2000; Özyürek, 2009, 2010a). There is a promising increase in studies and publications on counselor education and supervision especially in recent years (Kalkan \& Can, 2019). However, to our knowledge, there are no empirical studies on the accreditation of counselor education in Turkey.

Accreditation refers to an evaluation and independent quality assurance process, measuring whether the academic and field-specific standards, which have been predetermined by the accreditation authority are met by a higher education program (Council of Higher Education [CoHE], 2020). It has been more than forty years since counselor education started in Turkey, but the lack of a national standard on counselor education is having a negative impact on the identity of the profession. Although an accreditation body (i.e., Association for Evaluation and Accreditation of Teacher Education Programs; [AEATEP], 2021) has been accrediting counseling programs in Turkey, the standards of AEATEP has been questioned by counselor educators as even some of the basic concepts specific to the field such as "counselor" and "supervision," as well as names and standards of vocational counseling practices, school counseling internship, individual and group counseling courses have not been addressed. Additionally, the national representation of the currently suggested standards for counseling programs is in question as these standards were not opened to the discussion of the counselor educators in Turkey. As Topkaya indicated (2020), rapid developments in the 21st century triggered studies on determining desired competence of individuals in different occupational groups. Determining the competence of counselors is especially essential for the evaluation of counselor education programs and the performance of counselors. In Turkey, competence in the context of undergraduate education refers to the level of knowledge, capabilities, and qualifications of a person who graduated from any undergraduate program (CoHE, 2020). In Turkey, competencies at the undergraduate level are shaped according to the International Standard Classification of Education (ISCED, 2021) and National Qualifications Framework for Higher Education in Turkey, and Basic Field Competencies (CoHE, 2020). Competencies in the counseling profession are addressed in the Social Services and Fundamental Health Field (CoHE, 2020), whereas teacher competencies, which is the primary focus of the AEATEP, are addressed in the Teacher Training and Educational Sciences.

Though a counseling-specific accreditation body has not been established in Turkey until 2021, such establishments were found in other countries as early as 1981 [i.e., Council for Accreditation of Counseling and Related Educational Programs (CACREP)]. An examination of the standards of the CACREP and code of ethics in counseling-related professional associations [e.g., American Counseling Association (ACA), 2014; American School Counselor Association (ASCA), 2016; Turkish Psychological Counseling and Guidance Association's Code of Ethics (İkiz et al., 2021)], reveal the inadequacies of the AEATEP's standards for undergraduate level counselor education programs in Turkey. CACREP is an independent agency recognized by the Council for Higher Education Accreditation to accredit master's degree programs in addiction counseling, career counseling, clinical mental health counseling, marriage, 
couple, and family counseling, school counseling, student affairs, rehabilitation counseling, clinical rehabilitation counseling and college counseling in the United States. CACREP also accredits doctoral programs in Counselor Education and Supervision (CACREP, 2021). The CACREP standards are the driving force behind professional identity development and the agent that advances the counseling profession. CACREP (2020) and its 2016 accreditation standards play a significant role in advancing the counseling profession. Counselor educators have the power to influence students' knowledge, competence, and skills through classroom teaching and experiential learning in the programs. Similarly, counselor education programs need to prepare students to be capable, competent, and active leaders that will work towards continual change and growth (Chang et al., 2012). For this reason, CACREP has established a set of standards for counselor education programs, indicating knowledge and skills as an area of teaching for counselor educators (Barreto, 2012; CACREP, 2020). These guidelines reinforce the idea that professional counselors stimulate change, not only on a micro-level with individuals and families but also on a macro level, activating change in social, political, and professional organizations (ACA, 2014; Woo et al., 2016). Based on the CACREP accreditation standards, counselor education aims to promote professional identity and standardized curriculum through organizational and leadership participation (CACREP, 2020).

According to the 2016 accreditation standards set by CACREP (2020) under professional practice, practicum and internship are supposed to hone counseling skills with counseling practices under supervision. Counseling trainees should have at least 700 hours of practice under supervision. 240 hours of the aforementioned 700 hours of counseling practices should consist of counseling with real clients and direct services, such as individual and group counseling, classroom guidance activities. The remaining 360 hours comprise of supervision related to performance in the practice period and other indirect activities, including consultation, program development, and evaluation. The supervision process consists of two aspects: The first aspect involves receiving supervision from the site supervisor, who is in charge of counseling practices at the supervision site. The second aspect involves getting one hour of individual or triadic supervision and $60-90$ minutes of group supervision per week, from the faculty supervisor teaching the counseling internship course. The supervisor/supervisee ratio should not exceed 1/12.

To ensure equitable education across programs for diverse student groups, accreditation of counseling programs is pivotal not only in the US, but also in other countries (Haktanir, 2020). As evident in the CACREP standards addressed above, one of the important points of the accreditation process is the identification of the national standards of courses in education programs, especially for applied courses. Practicum courses in undergraduate-level counseling education in Turkey include career counseling practices, group counseling experiences, school counseling practices, and individual counseling practices. However, standards for the applied courses are not established in Turkish counseling programs and can greatly vary across programs. Moreover, there is a scant of regulations for counseling internship courses and various practices can be observed throughout the programs. The lack of standards across programs in applied courses has been reflected in the lack of studies in these areas. To exemplify, the first studies on these practicum courses and supervision began around 2010 with studies on school counseling (Atic1 \& Çam, 2013; Özyürek, 2009, 2010a, b), and followed by studies on courses regarding individual counseling practicum (Aladağ, 2014). Studies on applied career counseling and experience in group work are limited. 
The first studies on training and supervision of students matriculated in school counseling internships were conducted with senior college students from 19 different universities (Özyürek, 2009, 2010a, b). Özyürek (2009) collected data from these senior students $(n=365 ; 37.36 \%$ of the population) to examine time, structure, and feedback opportunities for practices in schools. Results of this study showed that a significant proportion of students did not receive individual or group supervision in a sufficient and regular manner and group supervisions were presented by inexperienced instructors and performed with crowded groups. Another study showed that senior students $(n=365)$ practiced classroom guidance $(\% 67)$, individual interviews (\%64), large group guidance $(\% 51)$, small group guidance $(\% 27)$, and school conferences (\%27) (Özyürek, 2010a). Study results also indicated that the mean individual counseling sessions conducted by senior students was $8.55(S D=7.97)$ and the mean attendance of senior students to group counseling sessions was 5.99 ( $S D=5.10$ ). The third study using the same sample (Özyürek, 2010b) examined school counseling internship in terms of (a) developing counseling and guidance programs, (b) program evaluation and accountability practices, (c) psychological test administration, (d) applying assessment techniques and (e) other practices (e.g., coordination, peer guidance, consultation, and orientation). The research sample consists of 345 senior students who graduated in 2006 (Özyürek, 2009, 2010a, b). Students who participated in the study reported a lack of competencies in the aforementioned areas. Additionally, students indicated applying assessment techniques comfortably in comparison to other areas. Other researchers (Atıc1 \& Çam, 2013) emphasized the improving and motivating effects of constructive feedback and suggestions from students and instructors. Atic1 and colleagues (2006) found that school counseling internship enhanced the perception of competence (school counselor competence, competence in evaluating profile scores, group counseling competence) and counseling self-efficacy. A study on developing draft standards of practicum classes by Demir et al. (2019) is considered to be another important development in recent years in the standardization of school counseling practices. During the second school counseling symposium, Demir and colleagues mentioned definitions of important counseling terminology, course definitions, principal methods used by school counselors, proposed prerequisite courses, learning outcomes of courses, practice opportunities provided to students, skills and duties of faculty or site supervisors, types of supervision and number of students in group supervision, proposed practices, starting and ending times of practices, evaluation criteria, determining measurement and evaluation tools for learning outcomes and explanations for proper ethical behavior. Some scholars also mentioned guidelines of interview and observation courses in counseling (Özyürek, 2019) and a roadmap for accreditation in Turkey (Özyürek \& Can, 2019).

There are several studies in the literature on individual counseling education and supervision in Turkey (Aladağ, 2014; Aladağ et al., 2011; Aladağ \& Kemer, 2016, 2017; Kalkan \& Can, 2019). Aladağ and Kemer (2017) reported that most counselors-in-training provided individual counseling to real clients, some counselors-in-training provided individual counseling to both real clients as well as classmates, and a small percentage only practiced with classmates. The authors indicated that, typically, most counselorsin-training worked with two real clients for eight to 10 sessions. Also, group supervision is reported to be the most common supervision method, performed with four to 22 psychological counselor trainees (Aladağ \& Kemer, 2017). There are no empirical study results related to group counseling practices and supervision in Turkey. The extant literature on both individual and group counseling practices and supervision are usually reviewed studies (Koçyiğit-Özyiğit \& İşleyen, 2016; Meydan, 2014; Y1lmaz \& Voltan-Acar, 2015). When studies on individual and group counseling are examined, there appears no consensus on the number of individual counseling sessions to be carried out, the number of group 
sessions to partake, the number of real clients to be seen, and the desired learning outcomes for applied individual and group counseling courses for undergraduate students. In short, although clinical supervision opportunity is indispensable for counseling process, there are no nationally defined and accepted clinical supervision practices and education standards in Turkey (Aladağ \& Kemer, 2016).

A literature review for career counseling practice courses shows a lack of studies on this area. Şeker and Çapri's study (2019) is the only available research on this subject. Researchers indicated that counselorsin-training experienced a growing period for group guidance, classroom guidance, and interviewing students. For instance, counseling candidates have the chance of getting awareness in occupational guidance. Students reported difficulties with the school principals in working in classes or taking clients out of classes. Additionally, communication problems with their classmates in their groups are among the reported issues. The research included opinions of school counselors serving as site supervisors at schools. These school counselors mentioned that the content of career counseling courses at universities should be in line with guidance and counseling services offered at the Turkish National Ministry of Education, and the assessment tools used in student screening should be made available in online settings.

The most important development toward the establishment of a counseling-specific accreditation body has been the development of self-assessment standards proposed by the initial voluntary accreditation committee (Turkish Psychological Counseling and Guidance Association Self-Assessment Report Preparation Committee, 2020). These standards are classified under "learning environments and professional counselor identity", "professional practices, interviews and observations", and "evaluating programs and results". These criteria address many critical topics for psychological counselors.

Considering the efforts of educational and professional institutions on determining competencies and standards towards increasing quality, developing national standards that would increase the quality of counselor education and the establishment of a counseling-specific accreditation body in Turkey are crucial. There are several critical and important topics pertaining to accreditation that warrants attention. Moreover, there is no known consensus on the standards among counselor educators. Therefore, seeking the opinions of experienced counselor educators on the standards of counselor education and determining important topics seem to be essential. Accordingly, this study aims to investigate opinions of counselor educators teaching undergraduate-level counseling courses in Turkey on critical accreditation issues, on which little consensus exists. These critical issues are, (a) the organizations that would accredit counseling programs, (b) course loading of instructors, (c) conditions of practicum and internship courses, (d) supervision possibilities, and (e) opportunities for providing counseling.

\section{METHOD}

\section{Participants}

The research population consists of instructors in 'Turkish public and private universities' undergraduatelevel counselor education programs. While state universities employ 615 instructors, private universities employ 265 instructors, a total of 880 counselor educators from 66 state and 27 private universities according to the report by the Turkish Psychological Counseling and Guidance Association İzmir Branch Research and Development Commission (2020). To maximize participation, we sent the study link to 641 counselor educators directly. We also strived to contact the rest of the counselor educators indirectly (i.e., through program chairs). The research sample consists of 265 instructors employed at the time of data collection in those programs who volunteered for this study and answered an online questionnaire 
via SurveyMonkey. While $71,53 \%$ of the participants answered all of the questions in the questionnaire $(n=201), 28,5 \%$ of the participants did not answer all of the questions. The first question in the questionnaire eliminated part-time employees of counselor education departments, which resulted in the removal of 13 participants. The sample size was therefore reduced to 201.

More than half of the participants (55,2\%) were females while 36,32\% of them were males. The remaining $11,48 \%$ did not declare their gender. Among the participants, $14,93 \%$ were full professors, $14,43 \%$ were associate professors, $27,36 \%$ were assistant professors, $8,46 \%$ were lecturers with a Ph.D., $1 \%$ were lecturers, 6,97\% were Ph.D. research assistants and 5,97\% were full-time research assistants without a Ph.D. Average work experience of the participants who declared their work experience $(n=154)$ was 13,90 years, with a standard deviation of 9,16. Total work experience ranges from 1 to 42 years. Average age $(n=155)$ was 41,46 , with a standard deviation of 10,20 . The ages of the participants ranged from 24 to 88 years.

Of the participants, $63,68 \%$ were employed in state universities, and 14,43\% were employed in private universities. When regional compositions of the participants were as follows: $13,09 \%$ of the participants were employed in the Marmara region, $11 \%$ in the Central Anatolia region, 5,03\% in the Mediterranean region, $8,2 \%$ in the Black Sea region, 6,08\% in from Aegean region, 4,03\% in Eastern Anatolia region, and $4,48 \%$ in Southeast Anatolia region. Only a small proportion of the participants $(2,08 \%)$ were employed at universities in the Turkish Republic of Northern Cyprus.

Participants who responded to the question related to graduation information primarily obtained undergraduate and graduate degrees from psychological counseling and guidance (PCG), guidance and psychological counseling (GPC), or Psychological Services in Education (PSE) departments (84\%; $n=$ 113). The remaining participants had their degrees in primary school teaching $(n=6)$, psychology $(n=2)$, pedagogy, philosophy, English language and literature, English teaching (one participant each). Some participants had their graduate degrees from counselor education, child psychology, educational sciences, curriculum and instruction, educational management and leadership, marriage and family therapy, developmental psychology, psychology, mental health counseling, management, and occupational psychology (one participant each). Of the participants who responded to this demographic information, $82,9 \%(n=132)$ reported earning their doctorate degrees from PCG/GPC/PSE departments.

\section{Ethical Statement}

This study was approved by the Gaziantep University's Social Science and Humanities Ethics Committee on August 19, 2020 (Board Approval Meeting Number: 13; Decision: 5). The participants were informed about the voluntary nature of participation before giving consent to take the survey.

\section{Data Collection Tools}

Research data were collected with "Questionnaire for Determining Opinions on Critical Accreditation Topics in Psychological Counselor Education" and demographic form, which was generated by the authors.

Demographic Form. This form collected demographic information of the participants including their age, gender, academic title, undergraduate, graduate, and doctorate programs, which practicum courses (career counseling, school counseling practices, individual counseling practices, and group counseling 
practices) they taught and for how long, work experience, the status of their universities (state or private) and location of their universities (7 geographic regions and the Turkish Republic of Northern Cyprus).

\section{Questionnaire for Determining Opinions on Critical Accreditation Topics in Counselor}

Education. Since the accreditation of counseling programs is a fairly recent discussed topic in Turkey, brief information was provided regarding the purpose of the study as well as the accreditation process of counseling programs in Turkey and the USA (i.e., CACREP). CACREP 2016 standards, Association for Evaluation and Accreditation of Medical Education Programs (AEAMEP, 2020) standards, Turkish Psychology Association (TPA) Psychology Undergraduate Programs Evaluation Criteria (TPA Psychology Programs Accreditation Unit, 2020), Association for Evaluation and Accreditation of Teacher Education Programs standards (AEATEP, 2020) and draft standards for school counseling practices (Demir et al., 2019) were used to determine critical and essential topics.

The questionnaire used in this study consisted of two sections. The first section focused on which institution(s) should have the responsibility in accrediting counseling programs. This section was created as the Association for Evaluation and Accreditation of Teacher Education Programs already grants accreditation status to undergraduate-level counselor education programs in Turkey. Additionally, at the time of this study, the Turkish Psychological Counseling and Guidance Association was in the process of establishing an independent accreditation body. In this section, opinions were collected on the necessity of the accreditation of undergraduate level counselor education programs, the necessity of foundation of an independent accreditation unit guaranteed by Turkish PCG Association guidelines, the definition of the field in the name of this unit, participation of instructors in studies, meetings, training conducted by this unit, accreditation status of their workplaces and if so, their problems and shortcomings.

The second section focuses on course loads of instructors, practicum courses, supervision opportunities for undergraduate students, and accreditation criteria/standards essential for counseling.

\section{Procedures}

Necessary ethical permission was obtained after developing the questionnaire. Then, we contacted the Turkish PCG Association and acquired the e-mail addresses of 641 faculty members in counselor education programs recorded in the Graduate Education Information System (GEIS). Those faculty members were first contacted on 31/08/2020, and the SurveyMonkey link accompanied the invitation. Our invitation includes the same link that was resent on 12.10.2020 to more than 100 program chairs or other responsible people in order for them to distribute to their members. Data were collected between 31/08/2020 and 28/10/2020. Each participant was allowed to access only from one device (e.g., smartphone, tablet). The average time spent on the questionnaire was 12.37 minutes.

\section{Data Analysis}

Descriptive statistics including frequencies and percentages, means, and standard deviations were calculated. Inappropriate questions, skewness, and kurtosis values were also calculated in order to determine the deviation from the normal distribution. Maximum values for skewness coefficient should not be higher than 3.00 and kurtosis coefficient should not be higher than 10,00 in order for distribution to be appropriate for single variable normal distribution (Kline, 1998). The range of these values were $.15-1.29$ for skewness and-.47 - 1.51 for kurtosis, hence were not reported separately. Some distributions deviated from normal distribution; therefore, relevant skewness, kurtosis, mean and 
maximum values were reported. SPSS 22.0 package software was used for quantitative analysis of data. Responses to open-ended questions were examined qualitatively.

\section{RESULTS}

\section{Personal information on practicum and internship courses}

There were several questions regarding four practicum and internship courses in the demographic questionnaire. Answers to those questions are included in this section instead of the Method section. Table 1 includes information on individual counseling practices (ICP), group counseling practices (GCP), career guidance practices (CGP), and school counseling internship (SCI) in schools, and course loads of instructors. Data revealed that individual counseling practices were the most frequently taught course, whereas, career guidance practices were the least.

One hundred thirty-three counselor educators reported that they had taught individual counseling practices courses (question \#9, Table 1). Participants mentioned teaching the course for an average of 6.62 years, with a standard deviation of 5.49. The range of answers for this question was between 1 and 36.

Only 68 counselor educators reported teaching group counseling courses (question \#10, table 1). This was similar to descriptive statistics of counseling practicum courses $(M=6.24, S D=6.16$, range $=1-36$, $M d n=4.50$, mode $=1.00)$. Distribution was peaked (7.07). The skewness value of 2.17 indicated a positively skewed distribution.

Sixty-seven participants responded the question \#11 (Table 1) on career guidance practices, relatively low participants answered this question. The mean answer for this question was 4.33 , and the standard deviation was 4.23. The range was between 0 and 25. The kurtosis value was 8.29, and the skewness was 2.48 , the median was 3.00 , and the mode was 1.00 .

SCI was the second most frequently taught course by counselor educators following ICP (question \#12, Table 1). The mean and standard deviations were close to each other for these questions $(M=6.16, S D$ $=5.66, M d n=5.00$, Mode $=2.00)$. The range was between 1 and 36. Kurtosis value was 6.75, which was again high as practicum and internship courses. The skewness was 2.18 .

\begin{tabular}{|c|c|c|c|c|c|c|c|c|c|}
\hline \multirow[t]{2}{*}{ No } & & \multicolumn{2}{|c|}{ ICP } & \multicolumn{2}{|c|}{ GCE } & \multicolumn{2}{|c|}{ CGC } & \multicolumn{2}{|c|}{ SCI } \\
\hline & & $n$ & $\%$ & $n$ & $\%$ & $N$ & $\%$ & $n$ & $\%$ \\
\hline \multirow[t]{2}{*}{8} & $\begin{array}{l}\text { "Which practicum courses are you } \\
\text { teaching/have you taught?" } \\
\text { (If none, please skip questioning \#49 }\end{array}$ & 132 & 65.67 & 64 & 31.84 & 58 & 28.86 & 105 & 52.24 \\
\hline & & & & $n$ & $M$ & $S D$ & & & \\
\hline 9 & $\begin{array}{l}\text { For how many years have you been tea } \\
\text { Counseling Practicum courses? (If zero, } p\end{array}$ & $\begin{array}{l}\text { ching } / \mathrm{t} \\
\text { please } \mathrm{sl}\end{array}$ & $\begin{array}{l}\text { ht Individual } \\
\text { this question) }\end{array}$ & 133 & 6.62 & 5.49 & & & \\
\hline 10 & $\begin{array}{l}\text { For how many years have you been } \\
\text { Counseling Experience courses? (If } \\
\text { question) }\end{array}$ & $\begin{array}{l}\text { teachin } \\
\text { zero, } \mathrm{p}\end{array}$ & $\begin{array}{l}\text { aught Group } \\
\text { se skip this }\end{array}$ & 68 & 6.24 & 6.16 & & & \\
\hline 11 & $\begin{array}{l}\text { For how many years have you been teac } \\
\text { Guidance Practices course? (If zero, pleas }\end{array}$ & $\begin{array}{l}\text { ching/t } \\
\text { se skip } t\end{array}$ & $\begin{array}{l}\text { ht the Career } \\
\text { question) }\end{array}$ & 67 & 4.33 & 4.23 & & & \\
\hline 12 & $\begin{array}{l}\text { For how many years have you been } \\
\text { counseling internships? (If zero, please sk }\end{array}$ & $\begin{array}{l}\text { teachin } \\
\text { kip this }\end{array}$ & $\begin{array}{l}\text { aught school } \\
\text { stion) }\end{array}$ & 109 & 6.16 & 5.66 & & & \\
\hline
\end{tabular}

Note. ICP $=$ individual counseling practicum, GCE $=$ group counseling experience, $\mathrm{CGC}=$ career guidance practices, $\mathrm{SCI}=$ school counseling internship 


\section{Topics Related to an Accreditation Body for Accrediting Counselor Education Programs at Undergraduate Level}

The first question of the second section of the survey was about the participant's employment status. Two hundred of the participants worked full-time while one participant reported working part-time. As shown in Table 2, 90.55\% of instructors supported accreditation of counselor education programs; $65.17 \%$ of them reported that their current institutions were not accredited by AEATEP; 63.18\% disagreed with the idea of accreditation of counselor education programs by AEATEP; 88.56\% agreed on accreditation of counselor education programs by a counseling-specific accreditation unit and its independence is guaranteed by the TPCGA; 46.27\% of the participants preferred "Counseling and Guidance Education" name, 37.31\% preferred "Counselor Education" as the name of the accreditation unit; $53.23 \%$ of the participants stated that "they will consider participating when the time comes" and $39.80 \%$ of the participants stated they would "definitely participate" in accreditation studies.

\section{Critical accreditation criteria/standards - Courseload}

Question \#10 pertaining to maximum course load was answered by 167 counselor educators (Table 2). The participants reported an average value of $13.77(S D=4.82)$ ranging from 2 to 30. This value was greater than the criterion established by the Council of Higher Education which is ten hours. Counselor educators reported (question 11) an average course load of 20.18 hours ( $S D=8.40)$, ranging from 2 to 47. The average counselor educator indicated (questions 12 and 13) teaching approximately 5 different courses per each semester. Participant responses ranged from 1 to 10. On average (question 14), our participants reported that the maximum number of new courses taught in a semester should not exceed $2(M=1.75, S D=.93)$, ranging from 1 to 5 . The total number of students both in the fall and spring semesters were almost similar for all participants (questions 15 and 16). Strikingly, a counselor educator had over 250 students $\left(M_{\text {fall }}=271.48, S D_{\text {fall }}=170.88 ; M_{\text {spring }}=266.61, S D_{\text {spring }}=180.60\right)$. CACREP (2016) proposed that the total number of full-time counselor educators working for at least three years to total student ratio should not exceed 1/12. Compared to the ratio reported in the 2016 CACREP standards (https://www.cacrep.org/section-1-the-learning-environment), counselor educators reported (question 17) a higher value (15.45), ranging from 1 to 100. The distribution was not normal (Skewness $=4.27$, Kurtosis $=30.79)$. Therefore, utilization of the median score would be more feasible. Both the median and mode were 12. The participants in the present study believed (question 18) that the maximum number of advisees should not exceed $22(M=21.99, S D=13.10)$ while the participants proposed numbers between 2 and 60. The nineteenth question in the questionnaire is an open-ended question allowing the participants to express their views and suggestions. The answers given to that question are summarized below.

\section{Critical accreditation criteria/standards - Conditions for practicum courses}

Of the participants, $79.10 \%$ answered question \#20 which is about attending conditional courses before proceeding to undergraduate level counseling practicum and school counseling internship courses as "I agree". All of the participants $(n=201)$ agreed with question \#21 that undergraduate-level counseling students should work with real clients. Of the participants, $75.62 \%$ agreed with question \#22 that each semester in the senior year (fall and spring), counseling practicum should be conducted with real clients under supervision. 
Answers to question \#23 which asked the least number of clients each undergraduate student would work within practicum have a mean of 3.18 with a range of $1-15$. This score demonstrates a non-normal distribution (Skewness $=3.31$, Kurtosis $=12.71$ ). Therefore, an interpretation of the median and mode values may be more feasible. Both the mode and median were 2. The counselor educators reported (question 24) that, on average, students should conduct at least 9 individual counseling sessions ( $M=$ 9.47, $S D=5.34$ ). Of the participants, $77.11 \%$ agreed that undergraduate students should experience group counseling in a mandatory course as a group member. Group counseling sessions included an average of 11.42 students (question \#26) with a range of 5-20. The participants reported (question \#26) that the maximum number of students in each group should not exceed $12(M=11.42, S D=2.88)$ with a range of 5 to 20. The counselor educators stated (questions \#27 and \#28) that the minimum number of weeks students should be involved in school counseling internship should last for approximately 10 weeks $(M=$ 10.03 weeks; range from 1 to 20), and eight weeks for career guidance practices ( $M=8.04$ weeks; range from 1 to 18). Question \#29 was an open-ended question exploring those issues.

\section{Critical accreditation criteria/standards - Supervision opportunities}

Of the participants, $74.13 \%$ agreed that at least $2 / 3$ of the instructors in counselor education departments should have Ph.D. degrees (Table 2).

We asked the participants to provide their opinions regarding the ideal counselor educator/group supervision student ratio. The mean value proposed by the counselor educators (question 31) was 10.97, which is lower than the ratio proposed by CACREP (2016), which is 1/12. However, participant responses demonstrated sharp and wide dispersion. In other words, the dispersion was not normally distributed (skewness $=3.80$, kurtosis $=29.90)$. Thus, it would be feasible to consider the median $(10.00)$ and mode values $\left(12 ; n_{\text {mode }}=51\right)$. Of the participants, $71.14 \%$ agreed that "supervisor/supervisee" ratios should be taken into consideration in the accreditation application and evaluation process (question \#32). When the ratio of graduate students providing supervision to undergraduate students receiving supervision is examined (question \#33), counselor educators stated an average value of 5.96 with responses ranging from 0 to 20 . In other words, counselor educators, on average, believe that the graduate student supervisor to undergraduate student ratio should be approximately $1 / 6$.

Approximately half of the participants (55.22\%) stated that all three supervision types (group, triadic and individual supervision) are necessary for practicum courses (question \#34, Table 2).

The average number of proposed individual supervision per student (question \#35) was 5.18 (Table 2). The responses ranged between 1 and 14, and showed a normal distribution (skewness $=.92$, kurtosis $=$ .20). Of the participants, $75.12 \%$ agreed that counselor educators providing supervision must have relevant counseling expertise and experience (question \#36).

\section{Critical accreditation criteria/standards - Counseling possibilities}

Counselor educators responding to the questions (questions \#38 and \#39) related to the number of individual or group counseling rooms in their counseling departments ( $n=28, n=32$; respectively), indicated an average individual counseling room (ICR) of 3.48 and 1.72 group counseling room (GCR) (Table 2). Though both distributions was near normal, the kurtosis value for group counseling rooms was

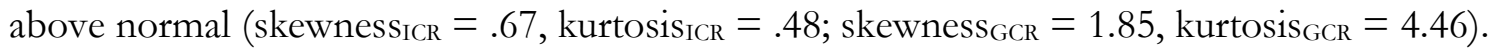


Table 2. Items and Results of the Exploration of the Counseling Faculty's Perspectives on the Crucial Areas of Accreditation in Counselor Education Programs Survey

1 I am a full-time faculty member in a counselor education program.

\begin{tabular}{|c|c|c|c|}
\hline \multicolumn{2}{|c|}{$\mathrm{Y}$} & \multicolumn{2}{|c|}{$\mathrm{N}$} \\
\hline$n$ & $\%$ & $n$ & $\%$ \\
\hline 200 & 99.50 & 1 & .50 \\
\hline \multicolumn{2}{|c|}{$\mathrm{N}$} & \multicolumn{2}{|c|}{ No Idea (NI) } \\
\hline$n$ & $\%$ & $n$ & $\%$ \\
\hline
\end{tabular}

Do you believe that the accreditation of the undergraduate level counselor education programs is necessary?

6.97

We have submitted an accreditation

Y N application to the

AEATEP and the application is being processed.

As of June 2020, the Association for Evaluation and Accreditation of Teacher Education Programs (AEATEP) accredited 15 counselor education programs (at the time of data collection of this study). Is the program you are currently

$n$

$\% \quad n$

$\%$

n $\%$

employed in AEATEP-accredited?

4 If you answered yes to the previous question or have submitted an accreditation application, please explain your perception of the relevance 4 of the AEATEP's criteria to counseling programs, whether you encountered any issues, etc. Please list the most important topics for you.

What do you think about the accreditation of counselor education programs by the AEATEP?

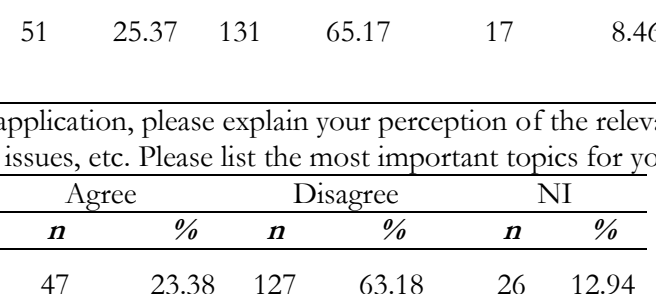

What do you think about the establishment of a new counseling-specific

6 accreditation body that is governed by counselor educators, and is recognized

as an independent body by the Turkish Psychological Counseling and Guidance

Association's (TPCGA) constitution?

178

$88.56 \quad 8 \quad 3.98$

13

6.47

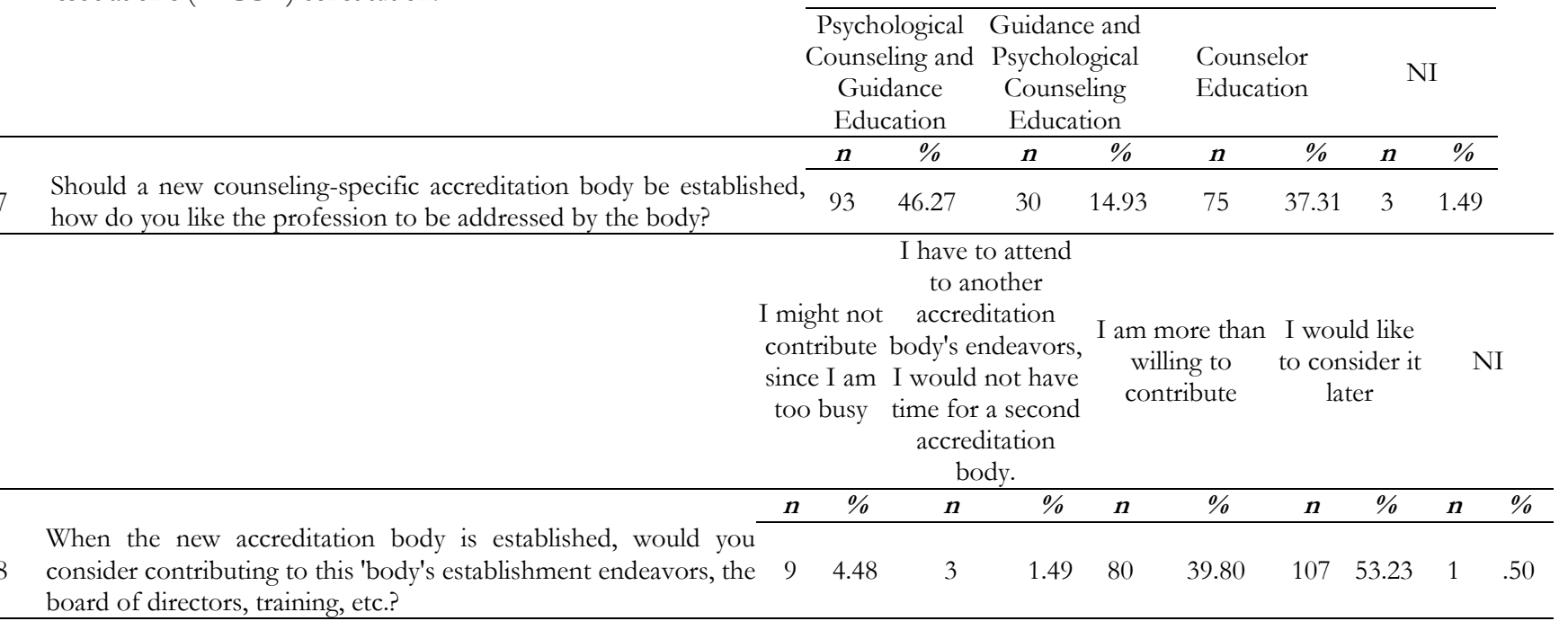

\section{Critical Accreditation Standards- Course Loads}

Given the mandatory course load of 10 hours determined by the Council of Higher Education, what do you think

10 about the upper limit per full-time counseling faculty with a Ph.D. (excluding advising and thesis/dissertation chairship hours)? (In answering this question, please count your course loads in other programs as well).

What is your current course load in the counseling program where you are employed full-time? Please exclude

11 advising and thesis/dissertation chairship hours.

How many different courses did you teach in the fall semester of the 2019-2020 academic year? In your response,

12 please count all undergraduate and graduate courses.

3 How many different courses did you teach in the spring semester of the 2019-2020 academic year? In your response, $164 \quad 5.25 \quad 2.14$ please count all undergraduate and graduate courses.

14 What do you think should be the maximum number of courses taught for the first time per semester?

15 What was the total number of students, approximately, in all your courses in the Fall semester of the 2019-2020

15 academic year? Please consider all your undergraduate and graduate courses.

\begin{tabular}{ccc}
$\boldsymbol{n}$ & $\boldsymbol{M}$ & $\boldsymbol{S} \boldsymbol{D}$ \\
\hline 167 & 13.77 & 4.82 \\
\hline 166 & 20.18 & 8.40 \\
\hline 164 & 5.20 & 2.10 \\
\hline 164 & 5.25 & 2.14 \\
\hline 167 & 1.75 & .93 \\
\hline 165 & 271.48 & 170.88
\end{tabular}


What was the total number of students, approximately, in all your courses in the Spring semester of the 2019-2020 academic year? Please consider all your undergraduate and graduate courses.

$166 \quad 266.61 \quad 180.60$

The Council for Accreditation of Counseling and Related Educational Programs (CACREP), the counselingspecific accreditation body in the USA, proposed that the total number of full-time counselor educators working for at least three years to total student ratio should not exceed $1 / 12$. What do you think about the maximum ratio (please only report the denominator of the ratio).

18 What do you think about the maximum number of advisees appointed per advisor?

\section{Critical Accreditation Standards for Applied Courses}

\begin{tabular}{|c|c|c|c|c|c|c|c|}
\hline & & \multicolumn{2}{|c|}{ Agree } & \multicolumn{2}{|c|}{ Disagree } & \multicolumn{2}{|c|}{ NI } \\
\hline & & $n$ & $\%$ & $n$ & $\%$ & $n$ & $\%$ \\
\hline 20 & $\begin{array}{l}\text { What do you think about the notion that students should meet the attendance requirements for } \\
\text { counseling theories, principles and techniques of counseling counseling skills, group counseling, career } \\
\text { counseling, ethics, and legal issues in counseling, and psychological assessment in counseling before } \\
\text { proceeding to the undergraduate level counseling practicum and school counseling internship courses? }\end{array}$ & 159 & 79.10 & 4 & 1.99 & 1 & .50 \\
\hline 21 & $\begin{array}{l}\text { What do you think about the idea that undergraduate-level counseling students should work } \\
\text { with real clients? }\end{array}$ & 201 & 100 & - & - & - & - \\
\hline \multirow[t]{2}{*}{22} & $\begin{array}{l}\text { What do you think about the notion that each semester in the senior year (fall and spring), } \\
\text { individual counseling practices course is conducted with real clients under supervision? }\end{array}$ & 152 & 75.62 & 10 & 4.98 & 1 & .50 \\
\hline & & & & $n$ & $M$ & $S D$ & \\
\hline 23 & \multirow{2}{*}{\multicolumn{3}{|c|}{$\begin{array}{l}\text { If you answered Agree to the question above, how many real clients, minimum, should undergraduate } \\
\text { level counseling students should work within skill-based courses, practicum, and internship courses? } \\
\text { What should be the minimum number of "individual counseling sessions" recorded and handed in by } \\
\text { counselors-in-training to faculty supervisors in individual counseling practicum courses? }\end{array}$}} & 154 & 3.18 & 2.46 & \\
\hline \multirow[t]{2}{*}{24} & & & & 161 & 9.47 & 5.34 & \\
\hline & & \multicolumn{2}{|c|}{ Agree } & \multicolumn{2}{|c|}{ Disagree } & \multicolumn{2}{|c|}{ NI } \\
\hline \multirow[t]{2}{*}{25} & $\begin{array}{l}\text { What do you think about the notion that undergraduate-level counseling students should take } \\
\text { a required group counseling course in which they have group membership experience? }\end{array}$ & 155 & 77.11 & 6 & 2.99 & 3 & 1.49 \\
\hline & & & & $n$ & $M$ & $S D$ & \\
\hline 26 & \multicolumn{3}{|c|}{$\begin{array}{l}\text { Should an undergraduate level applied group counseling course exist, what should be the maximum } \\
\text { number of students enrolled in a section? }\end{array}$} & 162 & 11.42 & 2.88 & \\
\hline 27 & \multicolumn{3}{|c|}{$\begin{array}{l}\text { What do you think about the minimum number of weeks that students should go to schools when } \\
\text { enrolled in applied school counseling courses (e.g., school counseling internship, fieldwork) per course } \\
\text { in a semester? }\end{array}$} & 161 & 10.03 & 3.14 & \\
\hline 28 & \multicolumn{3}{|c|}{$\begin{array}{l}\text { What do you think about the minimum number of weeks students should go to school when enrolled } \\
\text { in an applied school-based career guidance course (e.g., applied career counseling) per course in a } \\
\text { semester? }\end{array}$} & 160 & 8.04 & 3.21 & \\
\hline
\end{tabular}




\section{Critical Accreditation Standards for Supervision Practices}

\begin{tabular}{|c|c|c|c|c|c|c|c|}
\hline & & \multicolumn{2}{|c|}{ Agree } & \multicolumn{2}{|c|}{ Disagree } & \multicolumn{2}{|c|}{ NI } \\
\hline \multirow{3}{*}{30} & & $n$ & $\%$ & $n$ & $\%$ & $n$ & $\%$ \\
\hline & $\begin{array}{l}\text { What do you think about the notion that "At least } 2 / 3 \text { of the counselor } \\
\text { educators in a program should have a Ph.D. degree in Counselor Education } \\
\text { programs" (The } 2 / 3 \text { ratio was proposed by the Turkish Psychologists } \\
\text { Association and Psychology Programs Accreditation Bodv) }\end{array}$ & 149 & 74.13 & 7 & 3.48 & 3 & 1.49 \\
\hline & & & & $n$ & $M$ & $S D$ & \\
\hline 31 & $\begin{array}{l}\text { The Council for Accreditation of Counseling and Related Educationa } \\
\text { (CACREP) proposed that the faculty supervisor's ratio to the total } \\
\text { students enrolled in the faculty supervisors' course requiring group } \\
\text { should not exceed } 1 / 12 \text { ratio. What do you think about the maximum r } \\
\text { only report the denominator of the ratio)? }\end{array}$ & $\begin{array}{l}\text { al Pro } \\
\text { num } \\
\text { super } \\
\text { ratio }\end{array}$ & $\begin{array}{l}\text { grams } \\
\text { ber of } \\
\text { cvision } \\
\text { (please }\end{array}$ & 151 & 10.97 & 4.80 & \\
\hline
\end{tabular}

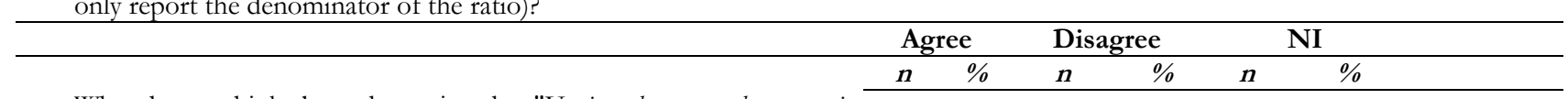

What do you think about the notion that "Various documents demonstrating

32 supervisor/student ratio in applied courses should be utilized as a criterion in the

32 review process of the accreditation application of the counselor education programs?

$\begin{array}{llllll}143 & 71.14 & 8 & 3.98 & 6 & 2.99\end{array}$

33 student? Please only report the denominator of the ratio.

\begin{tabular}{ccc}
\hline $\boldsymbol{n}$ & $\boldsymbol{M}$ & $\boldsymbol{S D}$ \\
\hline 137 & 5.96 & 4.30
\end{tabular}

\begin{tabular}{|c|c|c|c|c|c|c|c|c|}
\hline & \multicolumn{2}{|l|}{$\begin{array}{c}\text { Group } \\
\text { Sup. }\end{array}$} & \multicolumn{2}{|c|}{ Triadic Sup. } & \multicolumn{2}{|c|}{ Individual Sup. } & \multicolumn{2}{|c|}{$\begin{array}{c}\text { All Three } \\
\text { Types of } \\
\text { Sup. }\end{array}$} \\
\hline & $n$ & $\%$ & $n$ & $\%$ & $n$ & $\%$ & $n$ & $\%$ \\
\hline
\end{tabular}

34 Which of the following supervision type should be offered in applied courses?

$\begin{array}{llllllll}14 & 6.97 & 2 & 1 & 14 & 6.97 & 111 & 55.22\end{array}$

If you believe that individual supervision is necessary in addition to group

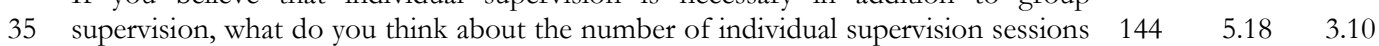
per student?

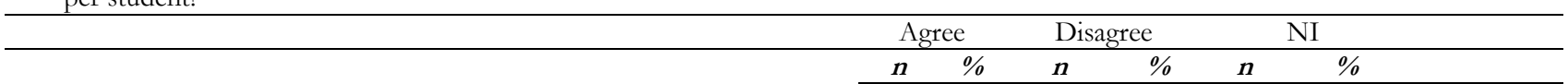

What do you think about the notion that Counselor educator supervisors must

36 have relevant experiences, professional competencies, and counseling supervision $\begin{array}{llllll}151 & 75.12 & 4 & 1.99 & 3 & 1.49\end{array}$ experiences?

\section{Critical Accreditation Standards for Counseling Facilities}

\begin{tabular}{|c|c|c|c|c|c|c|}
\hline \multirow[b]{3}{*}{38} & \multirow[b]{3}{*}{$\begin{array}{l}\text { How many individual counseling rooms are available for undergraduate and } \\
\text { graduate students in your department? }\end{array}$} & \multicolumn{2}{|c|}{$\begin{array}{l}\text { Rooms Do not } \\
\text { Exist }\end{array}$} & \multicolumn{3}{|c|}{ Rooms Exist } \\
\hline & & $n$ & $\%$ & $n$ & $M$ & $S D$ \\
\hline & & 28 & 13.93 & 129 & 3.48 & 1.85 \\
\hline & & $n$ & $\%$ & $n$ & $M$ & $S D$ \\
\hline 39 & $\begin{array}{l}\text { How many group counseling rooms are available for undergraduate and graduate } \\
\text { students in your department? }\end{array}$ & 32 & 15.92 & 126 & 1.72 & .96 \\
\hline
\end{tabular}

*The numbers omitted above elaborated participant comments and were not questions.

\section{Examination of Textual Responses}

Our survey allowed participants to type their comments and feedback at the end of each section. An examination of the comments and feedback revealed four themes: (a) establishment of the counselingspecific accreditation body, (b) content of self-study, (c) the initial voluntary accreditation committee, and (d) assessment of the current state of the counseling profession and programs. 
Question \#4: "If you answered yes to the previous question or have submitted an accreditation application, please explain your perception of the relevance of the AEATEP's criteria to counseling programs, whether you encountered any issues, etc. Please list the most important topics for you." Question \#9 is likewise open-ended and opinions and suggestions of participants were gathered. Answers to the \#4 and \#9 questions are summarized below.

\section{Establishment of Counseling-specific Accreditation Body}

Twenty-four individuals expressed their opinions regarding the accreditation process. Of these participants, 10 indicated the need for a counseling-specific accreditation body in Turkey and how it can contribute to the profession. Five respondents criticized the current approach of AEATEP toward accreditation of counseling programs. Four participants suggested a future-counseling-specific accreditation body be fully independent. Additionally, four participants reported concerns regarding the accreditation process and the amount of paperwork that may be required of counseling programs in the accreditation process. Finally, one participant offered recommendations regarding how to inform counseling programs across the country regarding the establishment of a counseling-specific accreditation body.

\section{The Content of Self-Evaluation Standards}

The second theme that emerged from participant comments was related to the content of self-evaluation. As mentioned earlier, most survey questions in the present study assessed counselor educators' views regarding potential accreditation standards. Forty-five participants offered their perspectives for potential accreditation standards and self-evaluation, which needs to be fulfilled by counseling programs to get accredited. Nine counselor educators highlighted the necessity of individual and group supervision, the need for limiting supervisor to supervisee ratio, and who should provide supervision (both counselor educators and student supervisors).

The second most commonly addressed comment pertained to skill-based courses. Eight individuals emphasized the importance of seeing clients from different backgrounds, the need for a broader perspective taking for career counseling, and the identification of pre-requisite courses for skill-based classes. Five out of six participants supported the standards related to minimum physical facilities of counseling programs (e.g., individual and group counseling rooms), whereas one addressed concern regarding this standard as the university administration provides physical facilities and counseling programs may have little control over it.

Additionally, six participants offered their viewpoints regarding rendering counseling services to real clients. Four respondents accentuated the value of counseling real clients while two addressed concerns regarding difficulty finding real clients. Another part of the self-evaluation standards that participants commented on was related to group counseling. Four out of five participants underscored the importance of group counseling and real group experience, whereas one participant proposed that a required group experience of students would be unethical. Finally, two respondents indicated concerns that what may be asked as a ratio of faculty to the student may not reflect the reality of counseling programs. 


\section{Initial Voluntary Accreditation Committee}

Five individuals delivered remarks on the initial voluntary accreditation committee. Three participants recommended either adding experienced counselor educators to the committee or asking for their point of view, while two participants questioned the way in which committee members were selected.

\section{Assessment of the Current State of the Counseling Profession and Programs}

The final theme that emerged from the responses was evaluating the current state of the counseling profession and programs. A total of 20 participants provided comments related to this theme. Six out of seven stated that physical facilities of their programs (e.g., individual or group counseling rooms) were insufficient, while only one indicated the number and conditions of counseling rooms to be satisfactory. Another topic addressed by several participants was supervision. Three participants complained that counselor educators do not receive a graduate-level supervision course and two criticized counseling programs for undervaluing supervision.

\section{DISCUSSION}

We analyzed essential discussion points among counselor educators and reviewed their opinions by a questionnaire. Course loads, the foundation of an accreditation institute, requirements for practicum and internship courses, supervision requirements, and counseling opportunities are among critical topics. Discussions of findings, as well as implications and conclusions, are shared below.

Results on experience in practicum and internship courses show that the most taught course by the counselor educators was the counseling practicum course. On the other hand, average teaching experience for career counseling practices, group counseling, school counseling practices, and counseling practicum courses ranged between 4.33 and 6.62 years. A great majority of the participants supported accreditation of counselor education, and this should be done by an accreditation unit of which independence is guaranteed by TPCGA. More than half of the participants disagreed with the idea that counselor education programs should be accredited by AEATEP. Participants preferred "Psychological Counseling and Guidance Education" and "Counselor Education" as the name of the accreditation unit.

Instructors' course load conditions (mandatory course hours, hours, of course, taught, course types, maximum number of courses to be taught the first time, number of students, instructor/student ratio, academic advisor/student ratio) show high values on mandatory course load, hours, of course, taught, number of students and course types. The instructor/student ratio $(1 / 15.45)$ was found to be higher than CACREP recommended ratio (1/12). The CACREP recommendation is for graduate programs; however, we sought counselor educators' overall opinion, including undergraduate and graduate programs. Therefore, it might be expected to find a student-to-faculty ratio that is higher than the CACREP recommendation. Additionally, findings pertaining to course loads are consistent with the findings of Özyürek (2009) which reported insufficient supervision conditions and crowded student groups, almost 15 years ago. We believe that a decrease in course loads of counselor educators can allow faculty members to allocate more time for students; thus, the quality of education that students receive can be improved.

Of the participants, $79.10 \%$ agreed that undergraduate students should partake in several theoretical courses before starting to take practicum and internship courses. All participants agreed that those courses should be performed with real clients, $75.62 \%$ said that those practices should be done in their 
final two semesters, with two to three real clients and for at least nine sessions. Özyürek (2009) reported the mean number of individual counseling sessions for senior students was 8.55. This finding is consistent with Aladağ and Kemer's (2017) findings which demonstrated that most participants saw at least two real clients and 7 to 10 sessions. But as Aladağ and Kemer indicated, a small percentage of the undergraduate students still continue to do counseling with their peers. Furthermore, few counselor educators shared in open-ended questions that students experience difficulty in finding real clients; thus, such a requirement (i.e., seeing real clients) may be cumbersome. Given the consistency between our results related to seeing real clients and other studies, it is reasonable to assume that experience with real clients is emphasized in counselor education undergraduate programs.

In another finding of the study, $77.11 \%$ of the participants supported undergraduate students getting experience in group counseling and stated that each group should have around 11 students. Participants also indicated that school counseling practices should last for 10 weeks, and career counseling practices should last for eight weeks in schools.

Among the results on supervision opportunities, $74.13 \%$ of the participants agreed that people with $\mathrm{Ph} . \mathrm{D}$. degrees in counseling should be employed in counselor education programs. Participants suggested that the "supervisor/supervisee" ratio (1/10) should be lower than CACREP 2016 standards (1/12). Though in reality, the supervisor/supervisee ratio is likely to be higher than $1 / 10$ in Turkey, such a recommendation by counselor educators might be provided to promote the quality of counselor education. "Graduate supervisor/undergraduate supervisee" ratio is around $1 / 6.71 .14 \%$ of the participants agreed on presenting these ratios as evidence in an evaluation period after the accreditation application. More than half of the participants (55.22\%) agreed on the need for all three supervision types (individual, group, and triadic supervision) and that the number of sessions in individual supervision should be five. Moreover, $75.12 \%$ of the participants reported that supervisors should have counseling supervision and supervision education.

The number of rooms for individual counseling was found four on average and the number of rooms for group counseling was found two on average in the universities where participants are employed. Unfortunately, not too many participants answered these two questions (28 and 32 participants respectively); therefore, it is difficult to draw conclusions related to the number of individual and group counseling rooms in counselor education programs. Subsequently, future research should strive to reach out to more counseling programs to obtain a more precise mean value.

More than 200 counselor educators from different universities all across Turkey participated in this study. The findings of this study illustrate that there was a general consensus among counselor educators on critical accreditation topics, such as seeing real clients, hiring faculty with a Ph.D. in counseling. Though we sought participants' perceptions and recommendations for ideal situations, there might be a considerable gap between reality and ideal. Future researchers can explore both the ideal and real simultaneously.

\section{Implications}

This study lays the foundation on critical accreditation issues on counselor education. Instructors' course loads, the number of different courses taught, the number of students are found to be excessive, and providing quality supervision may not be possible with such a high workload. Thus, while determining the accreditation standards in Turkey, instructors' course loads, the number of different courses taught 
and the number of students should be considered thoroughly. Therefore, preparation of "the directives on counseling practicum and internship courses" (Özyürek, 2019) would be beneficial.

\section{Limitations}

Although this study pioneers the standardization of undergraduate-level counselor education programs and therefore helps to determine accreditation criteria, as with any other study, this study also has its limitations. First of all, data was collected with a survey developed by the authors. Therefore, the study is limited to qualities that are measured through the questions in the survey. Finally, though we strived to reach out to all counselor educators across Turkey, we did not identify clusters to allow more national representation. Future researchers can pay more attention to the representation of all regions.

\section{Conclusion}

Considering the results of this study on essential criteria and important issues on counselor education in Turkey, the importance of an institution accrediting counseling programs becomes apparent. The findings of this study underscore the importance of the establishment of the Psychological Counseling and Guidance Education Programs Evaluation and Accreditation Unit. 


\section{REFERENCES}

ACA. (2014). 2014 ACA code of ethics. American Counseling Association. https://www.counseling.org/resources/aca-code-of-ethics.pdf

AEATEP. (2020). Association for Evaluation and Accreditation of Teacher Education Programs. https:/ / epdad.org.tr/?sDil=2

AEAMEP. (2021). Association for Evaluation and Accreditation of Medical Education Programs. http://www.tepdad.org.tr

Akkoyun. F. (1995). The job title and training issues in counseling: A review and implications. Turkish Psychological Counseling and Guidance Journal, 2(0), 1-21.

Aladağ, M. (2014). Critical incidents in individual counseling practicum supervision across different levels of counselor education. Ege Journal of Education, 15(2), 428-475.

Aladağ, M., Kağnıcı, D. Y., Cihangir-Çankaya, Z. C., Özeke-Kocabaş, E. Ö., \& Yaka, B. (2011). Developing group work competence in counselor education: Case of Ege University. Ege Journal of Education, 12(2), 21-43.

Aladağ M., \& Kemer, G. (2016) Clinical supervision: An emerging counseling specialty in Turkey. The Clinical Supervisor, 35(2), 175-191. http://dx.doi.org/10.1080/07325223.2016.1223775

Aladağ, M., \& Kemer, G. (2017). The examination of individual counseling practicum and its supervision in counselor education. İzmir, Turkey: Ege University, Directorate of Scientific Research Projects. https:/ / bit.ly/3Eo63Wo

ASCA. (2016). ASCA Ethical standards for school counselors. American School Counselor Association. https://www.schoolcounselor.org/getmedia/f041cbd0-7004-47a5-ba01-3a5d657c6743/EthicalStandards.pdf

Atıc1, M., \& Çam, S. (2013). Students' views on the course of counseling and guidance practice at schools. Turkish Psychological Counseling and Guidance Journal, 4(39), 106-119.

Atıc1, M., Özyürek, R., \& Çam, S. (2006). The effects of school counseling practices on counselor self-efficacy and occupational self-esteem: A longitudinal study. Turkish Psychological Counseling and Guidance Journal, 3(24), 7 26.

Barreto, A., (2012). Counseling for the training of leaders and leadership development: A commentary. The Professional Counselor, 2(3), 226-234. doi:10.15241/abb.2.3.226

CACREP. (2020). CACREP 2016 Standarts. The Council for Accreditation of Counseling and Related Educational Programs. https://cacrepdev.wpengine.com/for-programs/2016-cacrep-standards/

CACREP. (2021). Why should I choose an accredited program? The Council for Accreditation of Counseling and Related Educational Programs. https://www.cacrep.org/for-students/why-should-i-choose-an-accreditedprogram/

Chang, C. Y., Minton, C. A., Dixon, A.L., Myers, J. E., \& Sweeney, T. J. (2012). Professional counseling excellence throngh leadership and advocacy. Taylor \& Francis Group.

Council of Higher Education. (2020). National qualifications framework for higher education in Turkey. http://tyyc.yok.gov.tr/

Demir, M., Özyürek, R., Zeren, G., Köse, A., Akçıl, S., Buyruk Genç, A., \& Gökmen, G. (2019). The process of developing the draft standards of the applied courses related to school counseling in the guidance and psychological counseling programs and suggestions for the final form. School Counselor e-bulletin (9), p. 60-83.

Doğan, S. (2000). The need for accreditation of counseling programs and a model suggestion. Turkish Psychological Counseling and Guidance Journal, 2(14), 31-38. 
Haktanir, A. (2020). A comparison of counselling self-efficacy among international and domestic counselling students. Journal of Psychologists and Counsellors in Schools. Advance online publication. https://doi.org/10.1017/jgc.2020.19

ISCED. (2021). The international standard classification of education. https://ec.europa.eu/education/internationalstandard-classification-of-education-isced_en

İkiz, F. E., Baş, A. U., \& Arslan, Ü. (Eds.) (2021). Counseling code of ethics. Turkish Psychological Counseling and Guidance.

Kalkan, B., \& Can, N. (2019). Supervision in counselor education: Exploration of current status and standards in Turkey. Adiyaman University Journal of Educational Sciences, 9(2), 271-290. https://doi.org/10.17984/adyuebd.592894

Kline, R. B. (1998). Principles and practices of structural equation modeling. Guilford.

Koçyiğit-Özyiğit, M., \& İşleyen, F. (2016). Supervisor training in counseling Bolu Abant Į̇̌et Baysal University Journal of Faculty of Education, 16(4), 1813-1831.

Korkut, F., \& Mizıkac1, F. (2008). European Union, Bologna process and counselor education in Turkey. Educational Administration: Theory and Practice, 53(53), 99-122.

Meydan, B. (2014). A supervision model for counseling practicum: Microcounseling supervision model. Ege Journal of Education, 15(2), 358-374.

Özyürek, R. (2009). Counseling and guidance applications in school settings and supervision opportunities: A national survey. Turkish Psychological Counseling and Guidance Journal, 4(32), 54-63.

Özyürek, R. (2010a). School counseling practices in Turkish universities: Recommendations for counselor educators. Eurasian Journal of Educational Research, 39, 175-190.

Özyürek, R. (2010b). Identification of the application of school counseling practices carried out by students in counseling and guidance undergraduate program. Education and Science, 35(150), 160-174.

Özyürek, R. (2019, November 30-December 1). Guidelines for applied, interview, and observation courses in counseling [Conference session]. III. International Teacher Education and Accreditation Congress, Ankara, Turkey. https://educ.tedu.edu.tr/en/educ/agenda/events/iii-international-teacher-education-and-accreditationcongress

Özyürek, R., \& Can, A. (2019, November 30-December 1). A roadmap for development of accreditation in Turkey [Conference session]. III. International Teacher Education and Accreditation Congress, Ankara, Turkey. https://educ.tedu.edu.tr/en/educ/agenda/events/iii-international-teacher-education-and-accreditationcongress

Şeker, G., \& Çapri, B. (2019, November, 15-17). Vocational guidance and counseling practices: An evaluation from the perspective of psychological counselors candidates and school psychological counselors [Conference session]. IX. International Congress on Psychological Counseling and Guidance in Higher Education Proceedings, İstanbul, Turkey. https://bit.ly/3H85YHW

Topkaya, N. (2020). 21 st-century counselor competencies. In Ş. Terzi (Ed.), Counseling and guidance in schools (pp. 3560). Pegem Akademi.

TPA Psychology Programs Accreditation Unit. (2020). Psychology undergraduate programs accreditation standards. https://akreditasyon.psikolog.org.tr/

Turkish Psychological Counseling and Guidance Association İzmir Branch Research and Development Commission. (2020). Examination of the faculty members working in counselor education programs of the universities in Turkey and the Turkish Republic of Northern Cyprus in terms of titles and graduation status. İzmir. 
Turkish Psychological Counseling and Guidance Association Self-Assessment Report Preparation Committee (2020). Turkish psychological counseling and guidance association self-assessment report preparation guidebook. Unpublished manuscript.

Yllmaz, O., \& Voltan Acar, N. (2015). The importance of supervision in psychological counselor training and its role in group counseling. Bolu Abant İzet Baysal University Journal of Faculty of Education, 15(1), 342-356.

Woo H., Storlie, C. A., \& Baltrinic E. R., (2016). Perceptions of professional identity development from counselor educators in leadership positions. Counselor Education and Supervision, 55(4), 278-293. https://doi.org/10.1002/ceas.12054 


\section{About Authors}

Ragıp Özyürek. Ragıp Özyürek completed his undergraduate education at Hacettepe University, Faculty of Education, Department of Guidance and Psychological Counseling. He also received his master's degree in Hacettepe University Graduate School of Social Sciences Guidance and Psychological Counseling Master Program. Then, he completed her Ph.D. at Çukurova University Graduate School of Social Sciences, Guidance and Psychological Counseling program. Currently, he is working in İstanbul Aydın University Faculty of Education Department of Guidance and Psychological Counseling as a fulltime professor. Dr. Özyürek's fields of study/specialization include career counseling, school counseling, counselor education, statistics in counseling, and accreditation.

Nursel Topkaya. Nursel Topkaya completed her undergraduate education at Ege University, Faculty of Education, Department of Psychological Counseling and Guidance. She received her master's degree in METU Graduate School of Social Sciences Psychological Counseling and Guidance master's program. Then, she completed her Ph.D. in Psychological Counseling and Guidance program at Ege University Graduate School of Social Sciences. Currently, she is working at Ondokuz May1s University in the Psychological Counseling and Guidance program as an associate professor. Her areas of expertise include mental health, stigmatization of seeking mental health, intention to seek psychological help, and counselor education.

Abdulkadir Haktanır. Abdulkadir Haktanir is a Ph.D., who is an assistant professor of Psychological Counseling and Guidance at Necmettin Erbakan University, Turkey. He completed his Bachelor's degree in psychological counseling and guidance at Gaziosmanpaşa University, his master's degree in school counseling at Kent State University, and his Ph.D. in counselor education at Texas A\&M UniversityCorpus Christi. Abdulkadir was the recipient of the 2017 Exemplary Research and Practice Award: Doctoral Level, an award offered by the Association for Assessment and Research in Counseling- a division of the American Counseling Association. His research interests include suicide prevention and suicide assessment, multicultural counseling, positive psychology, ethics in counseling, and counseling self-efficacy.

Zeynep Hamamc1. Zeynep Hamamc1 graduated from Ankara University Faculty of Education, Department of Guidance and Counseling in 1992. She completed postgraduate studies at the Institute of Social Sciences at Ankara University and received his Ph.D. in Guidance and Counseling in 2002. She became an Associate Professor in 2006 and Professor in 2012. Currently, she is working in Gaziantep University, Faculty of Education, Department of Guidance and Counseling. Her academic research interests are psychodrama and cognitive behavior therapy.

Ahmet Can. Ahmet Can received his Ph.D. in Counselor Education and Supervision from Ohio University in 2015. Dr. Can earned his master's degree in School Counseling/Clinical Mental Health Counseling from Ohio University in 2012 and a bachelor's degree in Psychological Counseling and Guidance from Cukurova University in Turkey. Dr. Can has worked as a school, college, mental health counselor and clinical supervisor in a variety of settings including a primary, middle, and high school, college counseling center, and higher education. He currently works as an Assistant Professor and Program Coordinator/CACREP liaison for the Masters in Counseling Program in the Division of Psychology and Counseling at Governors State University. Dr. Can's major research and scholarship areas of interests include counselor education and supervision, school counseling, cross cultural counseling, international college students and psychological well-being. 
Baki Duy. Baki Duy earned his bachelor's degree in counseling and guidance from Hacettepe University in 1993. After graduating from the university, he received a scholarship given by the Ministry of Education to pursue a master's and doctoral degree in counseling abroad. He had completed his master's study in school counseling at St. John's University, New York. Dr. Duy pursued his postgraduate studies in counseling at the institute of education studies at Ankara University and earned his doctoral degree in 2003. He is currently working as a full-time professor in the counseling department in the education faculty at Anadolu University, Eskişehir. Among his research interests are cognitive-behavioral therapy, loneliness, and emotion regulation.

Süleyman Akç1l. Süleyman Akç1 received his Ph.D. in Counselor Education and Supervision from Kent State University in 2018. Dr. Akçll earned his master's degree in School Counseling from Kent State University in 2012 and a bachelor's degree in Elementary Education from Marmara University in Turkey. Dr. Akçıl has experience with elementary and middle school students as a school counselor, also has experience with young adults as a mental health counselor. Dr. Akçıl curretly works as a full time academician in the counseling department at Zonguldak Bülent Ecevit Üniversity. Dr. Akçıl's research interests include counselor education and supervision, school counseling, international students, cyberbullying, and perfectionism.

Olcay Y1lmaz. Olcay Y1lmaz graduated from Turkish Land Forces School's System Administration Sciences faculty with a bachelor's degree. Having his master's degree in Psychological Counseling and Guidance in Hacettepe University he completed his doctoral education in the same faculty of the same university. He worked as a psychological counselor, career counselor, and faculty member at different institutions. In 2018 Dr. Yilmaz started to work at TED University and is currently the vice-chair of the Department of Educational Sciences and a lecturer in the Guidance and Psychological Counseling Department. In addition to his sports psychology practices, he has researched career counseling focused on the personnel selection process and personality traits, scale development, cultural adaptation of psychological tests.

\section{Author Contribution}

Ragıp Özyürek. From the beginning of the research process, he has taken a leadership role in determining the research subject, writing the questionnaire items, making analyzes, and writing the chapters in the article.

Nursel Topkaya. She performed data collection, drafted the parts of the introduction and discussion sections of the manuscript, and copy-edited the whole manuscript.

Abdulkadir Haktanır. Abdulkadir contributed to survey development, writing the qualitative portion in the results section, translating the survey items as well as part of the results section from Turkish to English, and copy-edited the whole manuscript.

Zeynep Hamamc1. She contributed to the development of the measurement tool used in the research and the writing of the method section of the article.

Ahmet Can. He contributed to the introduction and literature review section of the manuscript. He also contributed the final version of the manuscript.

Baki Duy. BD contributed to the development of the research instrument and reviewed the whole manuscript.

Süleyman Akçıl. He contributed to the development of the measurement tool, took part in research design, copy-edited the whole manuscript and carried out editorial correspondence. 
Olcay Y1maz. He took part in the research design phase and development process of the measurement tool.

\section{Conflict of Interest}

It has been reported by the authors that there is no conflict of interest.

\section{Funding}

No funding support was received.

\section{Note}

This study was presented at the 22nd International Psychological Counseling and Guidance Congress, which was held in Muş, Turkey.

\section{Ethical Statement}

This research was completed in line with the Helsinki Declaration. In line with this, the study was investigated and permitted by Gaziantep University's Social Science and Humanitarian Ethics Board. Additionally, data tools in the study were only distributed to volunteer participants. All participants provided informed consent. Additionally, participants were informed that they could withdraw from the study at any time during data collection.

Ethics Committee Name: Gaziantep University's Social Science and Humanitarian Ethics

Board Approval Date: 19/08/2020

Approval Document Number: Board Approval Meeting Number: 13; Decision: 5 